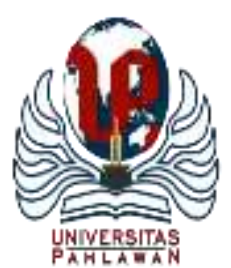

Edukatif : Jurnal Ilmu Pendidikan Volume 4 Nomor 1 Tahun 2022 Halm 963 - 969

EDUKATIF: JURNAL ILMU PENDIDIKAN

Research \& Learning in Education

https://edukatif.org/index.php/edukatif/index

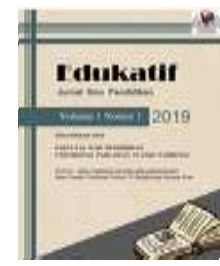

\title{
Pengaruh Bimbingan Orang Tua Terhadap Tanggung Jawab Belajar Siswa Sekolah Dasar
}

\author{
Niken Ayu Hapsari ${ }^{1}$, Roeth Amarlin Ochrissiati Najoan², Juliana Margareta Sumilat ${ }^{3 凶}$ \\ Universitas Negeri Manado, Indonesia ${ }^{1,2,3}$ \\ E-mail : $\underline{\text { nikenah59@ gmail.com }}^{1},{\underline{\text { roethnajoan@ } \text { unima.ac.id }^{2}}}^{\text {julianasumilat@ unima.ac.id }}{ }^{3}$
}

\begin{abstract}
Abstrak
Penelitian ini bertujuan untuk mengetahui pengaruh bimbingan orang tua terhadap tanggung jawab belajar siswa kelas V. Populasi dalam penelitian ini berjumlah 54 siswa dan sampel 48 siswa di kelas V SD Negeri II Tomohon. Penelitian adalah penelitian korelasional, menggunakan metode survei dengan pendekatan kuantitatif. Pengumpulan data dilakukan dengan menggunakan angket yang sudah di uji validitas dan reliabilitasnya. Data dianalisa dengan uji-t pada taraf signifikan $\alpha=0,05$, yang pada uji normalitas data $\mathrm{X}$ menunjukkan bahwa $\mathrm{L}_{\text {hitung }}=0,093<\mathrm{L}_{\text {tabel }}=0,128$, sedangkan untuk data $\mathrm{Y} \mathrm{L}_{\text {hitung }}=0,109<\mathrm{L}_{\text {tabel }}=0,128$ sehingga kedua data dapat dikatakan normal. Selanjutnya pada uji regresi linear sederhana menunjukkan persamaan $\mathrm{Y}=36,88063571+0,555591874 \mathrm{X}$ dimana bimbingan orang tua memberikan pengaruh yang positif. Hasil penelitian menunjukkan $\mathrm{t}_{\text {hitung }}=6,492>\mathrm{t}_{\mathrm{tabel}}=2,013$, maka dapat disimpulkan bahwa terdapat pengaruh yang signifikan dalam bimbingan orang tua terhadap tanggung jawab belajar siswa kelas V SD. Tanggung jawab belajar siswa dapat dijadikan sebagai salah satu tolak ukur untuk menilai keberhasilan suatu pendidikan di sekolah, dimana tanggung jawab belajar siswa dipengaruhi oleh berbagai faktor, salah satunya adalah bimbingan orang tua.
\end{abstract}

Kata Kunci: bimbingan orang tua, tanggung jawab belajar siswa.

\begin{abstract}
This study aims to find out the influence of parental guidance on the learning responsibilities of class $V$ students. The population in this study amounted to 54 students and a sample of 48 students in class V of State Elementary School II Tomohon. Research is correlational research, using survey methods with a quantitative approach. Data collection is done using questionnaires that have been tested for validity and reliability. Data analyzed with $t$-test at a significant level $\alpha=0.05$, which on the normality test data $X$ shows that $L_{\text {calculate }}=$ $0.093<L_{\text {table }}=0.128$, while for data $Y L_{\text {calculate }}=0.109<L_{\text {table }}=0.128$ so that both data can be said to be normal. Furthermore, the simple linear regression test shows the equation $Y=36.88063571+0.555591874 X$ where parental guidance exerts a positive influence. The results showed $t_{\text {calculate }}=6,492>t_{\text {table }}=2.013$, it can be concluded that there is a significant influence in parental guidance on the learning responsibilities of grade $V$ elementary students. Student learning responsibilities can be used as one of the benchmarks to assess the success of an education in school, where students' learning responsibilities are influenced by various factors, one of which is parental guidance.
\end{abstract}

Keywords: parental guidance, student learning responsibilities

Copyright (c) 2022 Niken Ayu Hapsari, Roeth Amarlin Ochrissiati Najoan, Juliana Margareta Sumilat $\triangle$ Corresponding author

Email : julianasumilat@unima.ac.id

DOI : https://doi.org/10.31004/edukatif.v4i1.1839

ISSN 2656-8063 (Media Cetak)

ISSN 2656-8071 (Media Online) 
964 Pengaruh Bimbingan Orang Tua Terhadap Tanggung Jawab Belajar Siswa Sekolah Dasar - Niken Ayu Hapsari, Roeth Amarlin Ochrissiati Najoan, Juliana Margareta Sumilat

DOI: https://doi.org/10.31004/edukatif.v4i1.1839

\section{PENDAHULUAN}

Ketika seorang anak mulai mengenal dunia luar maka ada beberapa hal yang mulai mempengaruhi kehidupannya. Dimulai dari lingkungan keluarga, sekolah dan masyarakat. Masing-masing lingkungan memiliki fungsi yang berbeda-beda dan mampu membawah perubahan atas aktivitas anak. Peran keluarga terutama orang tua sangat dibutuhkan dalam membantu pembentukan berbagai kemampuan anak dan untuk mempersiapkan masa depannya. Suatu pencapain yang besar tidaklah diperoleh secara intens, melainkan melalui suatu proses panjang yang kemudian dibekali dengan usaha dan kesabaran dalam mempelajari berbagai hal demi memperoleh perubahan pada diri individu. Puncak keberhasilan seseorang tidaklah diperoleh secara sepihak tetapi ada bantuan yang diberikan oleh pihak lainnya, seperti halnya keberhasilan seorang anak yang selalu didukung oleh orang tua dan lingkungan sekitar. Rasa puas akan puncak keberhasilan seseorang pada akhirnya akan disyukuri oleh kedua belah pihak karena berhasilnya tujuan yang ingin digapainya mencapai kesuksesan.

Demi menciptakan masa depan yang gemilang maka anak akan melalui proses belajar dalam hidupnya, dimana belajar merupakan serangkain proses perubahan yang dibentuk oleh individu dan perubahan tersebut ditampakkan dalam bentuk peningkatan kualitas dan kuantitas tingkah laku seperti peningkatan kecakapan, pengetahuan, sikap, kebiasaan, pemahaman, keterampilan, daya pikir, dan kemampuan-kemampuan yang lain (Sumilat J M, 2020). Begitu banyak kemampuan yang diperoleh dari proses belajar memungkinnkan seseorang mampu menjadi pribadi yang lebih baik, transformasi yang diterima memiliki dampak yang besar pada karakteristik dan kapasitas seseorang dalam mengolah berbagai ilmu pengetahuan yang ditemuinya. Kegiatan belajar akan berjalan dengan baik jika terdapat unsur-unsur yang identik atau berkaitan antara kegiatan yang pernah dilakukan siswa dengan kegiatan baru yang dihadapinya (Najoan, 2011). Dengan kata lain ketika anak mempelajari sesuatu yang baru akan lebih mudah dipahami jika dihubungkan dengan sesuatu yang pernah mereka pelajari sebelumnya. Maka setiap sesuatu yang mereka pelajari sebelumnya akan menumbuhkan perubahan baru dalam diri mereka. Oleh karena itu pembelajaran dapat dikatakan efektif apabila terdapat perubahan pada diri orang tersebut, misalkan yang tidak tahu menjadi tahu (Pratiwi and Aslam 2021). Adapun keberhasilan pada pembelajaran tersebut tak lepas dari bimbingan yang diberikan oleh seseorang. Terlebih pencapain belajar seorang anak berpatokan pada sebesar apa bimbingan yang ia terima, semakin besar bimbingan yang ia peroleh maka semakin besar pula perkembangannya, begitu pula sebaliknya semakin kecil bimbingan yang diberikan maka semakin sempit pula pertumbuhannya.

Dengan demikian bimbingan adalah suatu proses pemberian bantuan kepada individu secara berkelanjutan dan sistematis, yang dilakukan oleh seorang ahli yang telah mendapat latihan khusus untuk itu, dimaksudkan agar individu dapat memahami dirinya, lingkungannya serta dapat mengarahkan diri dan menyesuaikan diri dengan lingkungan untuk dapat mengembangkan potensi dirinya secara optimal untuk kesejahteraan dirinya dan kesejahteraan masyarakat (Basri, 2018). Hal ini berarti bimbingan dapat dilakukan oleh siapa saja yang telah ahli atau memiliki pengetahuan yang luas demi mencapai suatu perubahan dalam diri individu tersebut, sehingga ia mampu bersosialisasi dengan baik di berbagai lingkungan. Bukan sekedar mengenal lingkungan sekitar saja namun individu juga cakap dalam pembelajaran baik pada pengembangan minat dan bakatnya.

Demikian pula dengan yang disampaikan oleh (Juniarti 2021) bahwa bimbingan adalah suatu proses pemberian bantuan terus menerus dan sistematis kepada individu dalam memecahkan masalah yang dihadapinya, agar tercapai kemampuan untuk dapat memahami dirinya, kemampuan untuk menerima dirinya, kemampuan untuk mengarahkan dirinya, dan kemampuan untuk merealisasikan dirinya sesuai dengan potensi atau kemampuanya dalam mencapai penyesuaian diri dengan lingkungan, baik keluarga, sekolah, maupun masyarakat. Hal ini merujuk bagaimana seseorang mengerti dengan tujuan hidupnya, yang tanpa ragu melangkah kedepanya dengan percaya diri atas kemampuan yang dimilikinya. Meski banyak masalah yang 
965 Pengaruh Bimbingan Orang Tua Terhadap Tanggung Jawab Belajar Siswa Sekolah Dasar - Niken Ayu Hapsari, Roeth Amarlin Ochrissiati Najoan, Juliana Margareta Sumilat

DOI: https://doi.org/10.31004/edukatif.v4i1.1839

ditemui namun seseorang yang mampu mengontrol diri dan menyesuaikan diri dengan situasi apapun pastinya sanggup untuk menghadapinya. Demi mencapai sesuatu yang hebat diperlukan proses yang panjang, oleh karena itu orang tua harus benar-benar bersabar dalam membimbing anak agar ia mampu menggapai sikap tanggung jawab dalam dirinya dan memperoleh ilmu pengetahuan yang berguna. Karena bimbingan mampu memeberikan dampak psikologi yang baik dalam meningkatkan rasa percaya diri dan optimisme belajarnya siswa (Parnata, Kristiantari, and Putra 2014).

Namun siswa sekolah dasar sensitif dalam menimbulkan kekeliruan sehingga ia tidak mengerti tentang tanggung jawab yang dimilikinnya terutama mengenai tanggung jawab belajarnya. Yang dimana tanggung jawab belajar merupakan suatu kesadaran, keberanian, dan kewajibanan yang dimiliki siswa untuk melaksanakan tugas belajarnya yang dimanifestasikan dalam bentuk tindakan, perilaku, atau kebiasaan dan siap menangggung segala macam akibat dan konsekuensi atas tindakan tersebut dengan penuh kerelaan hati (Hariandi et al. 2020). Karakter tanngung jawab dapat dikatakan sebagai sifat seseorang yang setia dan konsekuen atas setiap perbuatan yang dilakukan, sehingga bertindak seseuai dengan kewajiban atas penyelesaian perbuatan yang dilakukan (Aliyah 2019). Kondisi ini bermakna seseorang paham akan pekerjaan dan kewajiban yang seharusnya ia kerjakan dengan sukarela tanpa paksaan dari pihak lain. Tidak hanya sadar akan tugas dan kewajibannya namun paham atau mengerti dengan apa yang seharusnya ia lakukan dan yang tidak seharusnya ia lalai terhadap tugas dan kewajibannya, sehingga menghasilkan pencapaian yang maksimum dan kebahagiaan untuk diri sendiri karena tercapainnya tujuan yang sinkron dengan apa yang diharapkan.

Tentunya tidak semua anak mampu untuk bertanggung jawab terlebih dalam belajarnya. Beberapa hal yang banyak dijumpai pada kenyataan saat ini adalah orang tua yang kurang dapat memberikan waktu dan bimbingannya secara penuh membuat siswa sering lalai dalam tanggung jawabnya. Seorang anak yang mampu bertanggung jawab dalam belajar akan senantiasa rajin dan disiplin dalam belajar maupun terhadap tugas lainnnya. Sebaliknya seorang anak yang tidak bertanggung jawab dalam belajar akan mendapatkan hasil yang kurang maksimal, sehingga ia tidak dapat mengetahui seberapa besar hasil kemampuan dirinya (Syafitri, 2017). Hal seperti ini tidak hanya terjadi pada saat ini melainkan ada beberapa peneliti terdahulu yang juga menyadari hal yang sama yaitu kurangnnya waktu dan bimbingan yang diberikan oleh orang tua pada anakanaknya.

Seperti penelitian yang dilakukan oleh Nugraheni (2015) yang berjudul Pengaruh Bimbingan Belajar Orang Tua Terhadap Prestasi Belajar Siswa Kelas Tinggi SD Negeri Jagoan 1 Tahun Pelajaran 2014/2015 yang dalam penelitiannya bertujuan untuk mengetahui ada tidaknya pengaruh bimbingan belajar orang tua terhadap prestasi belajar siswa, serta seberapa besar pengaruh yang diberikan oleh variable bimbingan belajar orang tua terhadap prestasi belajar siswa. Temuan dari penelitian ini menemukan bahwa ada pengaruh dari bimbingan belajar orang tua terhadap prestasi belajar siswa sebesar 63,9\%. Dengan demikian semakin baik bimbingan belajar yang diberikan oleh orang tua kepada siswa, maka semakin baik pula prestasi belajar siswa tersebut. Begitu pun sebaliknya jika bimbingan belajar yang diberikan oleh orang tua kepada siswa berkurang, maka prestasi belajar siswa pun akan semakin rendah (Nugraheni 2015).

Dari temuan tersebut dapat menjadi pertimbangan bagi penulis mengenai begitu pentingnya bimbingan belajar orang tua terhadap prsestasi belajar siswa, namun yang menjadi fokus dalam penelitian saya bukan sekedar bimbingan belajar yang diberikan oleh orang tua dan bukan hanya sekedar prestasi belajar siswa. Tetapi yang menjadi fokus penelitian saya yaitu bimbingan yang diberikan oleh orang tua sepenuhnya dan tanggung jawab belajar yang dimiliki oleh siswa. Karena alasan inilah penulis tertarik untuk melakukan penelitian ini yang berjudul pengaruh bimbingan orang tua terhadap tanggung jawab belajar siswa kelas V SD. 
966 Pengaruh Bimbingan Orang Tua Terhadap Tanggung Jawab Belajar Siswa Sekolah Dasar - Niken Ayu Hapsari, Roeth Amarlin Ochrissiati Najoan, Juliana Margareta Sumilat

DOI: https://doi.org/10.31004/edukatif.v4i1.1839

\section{METODE PENELITIAN}

Penelitian ini merupakan jenis penelitian korelasional (Putra and Dewi 2016), yang menggunakan metode penelitian survei dengan pendekatan kuantitatif. Penelitian korelasi adalah penelitan yang bertujuan untuk melihat hubungan antara satu variable dengan variable lainnya (Nasehudin and Gozali 2012). Penelitian ini dilaksanakan di kelas V SD Negeri II Tomohon, pada 23 Maret hingga 20 Mei 2021. Dalam penelitian ini, populasi penelitian berjumlah 54 siswa. Dari jumlah poulasi tersebut maka sampel yang ideal pada taraf signifikansi 5\% yaitu sebesar 48 siswa, yang masing-masing kelas diambil 24 siswa secara acak. Untuk memperoleh data peneliti menggunakan angket yang telah diuji validates dan reliabilitasnya. Anglet terdiri dari 25 butir soal. Uji validitas dilakukan dengan rumus korelasi product moment $\left(r_{x y}\right)$ yang menggunakan bantuan microsoft excel. Uji reliabilitas menggunakan rumus Alpha Cronbach dan juga memerlukan bantuan microsoft excel. Uji persyaratan yang dilakukan adalah pengujian normalitas data menggunakan liliforce dan uji lineriatas data menggunakan uji regeresi sederhana. Selanjutnya peneliti melakukan uji hipotesis yang dianalisa dengan Uji-t dan menggunakan microsoft excel. Adapun hipotesis dalam penelitian ini adalah terdapat pengaruh yang signifikan antara bimbingan orang tua terhadap tanggung jawab belajar siswa kelas $\mathrm{V}$ SD Negeri II Tomohon. Hipotesis penelitian tersebut dapat diterima jika $t_{\text {hitung }}>t_{\text {tabel }}=2,013$.

\section{HASIL DAN PEMBAHASAN PENELITIAN}

Hasil uji normalitas menunjukkan nilai $\mathrm{L}_{\text {hitung }}=0,092717519$ pada data $\mathrm{X}$, sedangkan pada data $\mathrm{Y}$ diperoleh nilai $\mathrm{L}_{\text {hitung }}=0,10907388$ dan nilai $\mathrm{L}_{\text {tabel }}=0.128$ dengan taraf nyata $\alpha=0,05$. Diketahui bahwa $\mathrm{L}_{\text {hitung }}$ $<\mathrm{L}_{\text {tabel }}$ maka dapat kedua data dikatakan normal. Setelah dilakukan uji normalitas, dilanjutkan dengan uji regresi linear sederhana berdasarkan data yang terkumpul tentang bimbingan orang tua dan tanggung jawab belajar siswa yang kemudian dilakukan perhitungan data agar memperoleh hasil yang lebih terperinci. Hasil uji lineriatas menunjukan persamaan regresi linear sederhana yang diperoleh adalah $\mathrm{Y}=36,88063571+$ $0,555591874 X$. Dari persamaan tersebut dapat dikatakan bahwa bimbingan orang tua memberikan pengaruh yang bersifat posotif.

Penelitian dilanjutkan dengan menguji hipotesis, dengan melakukan uji-t. Hasil uji hipotesis dengan taraf signifikan $\alpha=0,05$ diperoleh $t_{\text {hitung }}=6,492,>t_{\text {tabel }}=2,013$. Berdasarkan hasil uji hipotesis tersebut maka dapat ditarik keputusan menolak $\mathrm{H}_{0}$, dan menerima $\mathrm{H}_{1}$, yang artinya terdapat pengaruh yang signifikan antara bimbingan orang tua terhadap tanggung jawab belajar siswa kelas $\mathrm{V}$.

Temuan penelitian ini sejalan dengan temuan penelitian Jeklin (2016) yang menemukan bimbingan belajar orang tua berpengaruh positif dan signifikan terhadap tanggung jawab belajar siswa. Hasil penelitian ini menguatkan bahwa tanggung jawab belajar siswa ditentukan salah satu faktornya adalah bimbingan orang tua. Selanjutnya penelitian Melati et al., (2021) menambahkan bahwa tanggung jawab merupakan sikap atau perilaku individu yang mau melaksanakan tugas dan kewajibannya terhadap diri sendiri, orang lain, masyarakat dan negara serta kewajiban terhadap Tuhan. Sedangkan (Pangastuti et al. 2020) menemukan bahawa pendampingan orang tua saangat berpengaruh terhadap kemandirian dan tanggung jawab belajar dari rumah, namun terdapat perbedaan pada objek yang diteliti yaitu penelitianannya pada siswa TK atau RA. Hal ini menyatakan bahwa dari tingkatan TK atau SD sama-sama memerlukan bimbingan orang tua dalam menumbuhkembangkan tanggung jawab belajar siswa.

Selanjutnya temuan penelitian Lagiana (2017) menyatakan bahwa terdapat pengaruh yang signifikan antara bimbingan orang tua terhadap perilaku belajar siswa pada kelas IV dan V, dimana pengaruh yang diberikan oleh bimbingan orang tua lebih besar dibanding pola asuh orang tua. Dari temuan Lagiana dapat dilihat jika bimbingan orang tua memberikan pengaruh yang lebih besar terhadap perilaku belajar siswa, dimana temuan ini membuat peneliti semakin yakin akan pengaruh yang diberikan dengan memusatkan bimbingan orang tua terhadap anak di rumah sangat membantu proses perkembangan anak dari sikap 
967 Pengaruh Bimbingan Orang Tua Terhadap Tanggung Jawab Belajar Siswa Sekolah Dasar - Niken Ayu Hapsari, Roeth Amarlin Ochrissiati Najoan, Juliana Margareta Sumilat

DOI: https://doi.org/10.31004/edukatif.v4i1.1839

tanggung jawab belajarnya. Namun perkembangan yang diterima bukan sekedar perubahan pada satu faktor namun dapat mempengaruhi berbagai faktor lainnya yang ada pada diri anak. Disini ditemukan bahwa bimbingan orang tua memberikan pengaruh dengan arah positif sebesar $53,77 \%$, sedangkan hasil penelitian yang saya temukan bimbingan orang tua memberikan pengaruh terhadap tanggung jawab belajar sebesar 97,03\%. Dengan ini dapat dikatakan bimbingan orang tua sangat penting untuk diterapkan dalam diri anak, agar anak mampu menjadi sosok yang bertanggung jawab atas kegiatan belajarnya terlebih pada hidupnnya.

Sedangkan hasil temuan dari Tarbiyah et al. (2010) yang menyatakan bahwa terdapat pengaruh tanggung jawab belajar melalui bimbingan belajar orang tua, namun dengan tingkat koefisien korelasi positif rendah. Sehingga pada penelitiannya ia merekomendasikan perlunnya meningkatkan tanggung jawab belajar anak dengan cara orang tua menyempatkan diri di tengah-tengah kesibukan untuk mendampingi dan memberikan semangat agar anak mampu mencapai hasil yang maksimal. Dimana tanggung jawab belajar adalah suatu proses dimana seseorang berinteraksi lansung menggunakan semua alat indranya terhadap objek belajar dan lingkungan melalui pendidikan yang menghasilkan perubahan tingkah laku seperti pengetahuan, cara berpikir, keterampilan, sikap, nilai dan kesediaan menanggung segala akibat dari kegiatan belajar dengan penuh kesadaran, kerelaan, rasa memiliki, dan disiplin yang bertujuan untuk menguasai materi ilmu pengetahuan (Monica and Gani 2016). Sikap tanggung jawab belajar mampu mendewasakan seseorang sekalipun ia adalah siswa sekolah dasar. Mampu menerima sangsi dari kesalahan yang telah diperbuat, mengiklaskan sesuatu yang bukan untuknya, tidak lalai dalam menjalankan tugas, selalu tepat waktu dan mampu menguasai materi pembelajaran merupakan sesuatu yang sulit untuk dilakukan anak sekolah dasar karena itulah dibutuhkan bimbingan dari orang tua agar mencapai hasil yang memuaskan.

Sama halnya dengan penelitian yang dilakukan oleh (Ansel and Pawe 2021) yang meneliti tentang pengaruh bimbingan belajar orang tua terhadap disiplin belajar siswa sekolah dasar. Dimana semakin tinggi bimbingan orang tua maka semakin tinggi disiplin belajar siswa, sebaliknya semakin rendah bimbingan orang tua maka semakin rendah disiplin belajar siswa. Penelitian ini memiliki kemiripan dengan penelitan yang saya lakukan yaitu disiplin belajar dan tanggung jawab belajar siswa menjadi salah satu faktor penunjung keberhasilan prestasi yang optimal.

Keterbatasan penelitian ini yang juga menjadi rekomendasi yang harus diperhatikan oleh penelitipeneliti lainnyaadalah jumlah responden 48 orang. Jumlah sampel ini dirasa masih kurang dan akan jauh lebih baik jika jumlah responden lebih banyak. Selanjutnya penelitian ini hanya meneliti pada kelas V dan hanya pada satu sekolah sehingga hasil cakupan kurang luas, namun akan berbeda jika tempat penelitian lebih dari satu sekolah atau lebih banyak tingkatan kelas sehingga hasil cakupan akan lebih akurat.

Peneliti melakukan penelitian ini berharap jika suatu saat nanti dapat membantu seseorang yang telah membaca penelitian ini, terutama kepada pihak orang tua dapat dijadikan cerminan atau contoh dalam memperbaiki hubungan dengan anak melalui pemberian bimbingan atau bantuan kepada anak secara teratur dan bertahap mampu membuat anak lebih gampang didekati sehingga ia lebih terbuka dari sebelumnya. Sejalan dengan yang dikemukakan oleh Astuti, Arso, dan Wigati (2015) bimbingan orang stua adalah petunjuk atau penjelasan cara mengerjakan sesuatu hal yang dilakukan oleh orang tua terhadap anak-anaknya. Situasi ini berarti bimbingan yang diberikan berupa arahan dalam menyelesaikan beberapa pekerjaan atau tugas. Orang tua dapat mengajarkan banyak hal pada anak, mulai dari hal-hal kecil hingga ke hal-hal besar jika anak sudah mampu untuk mengerjakannya. Ketika anak kesulitan dalam mengerjakan tugas yang diluar dari kemampuannya mungkin akan memakan banyak waktu dan menghabiskan banyak tenaga namun jika orang tua berperan dengan baik dan memberikan arahan dengan jelas akan membuat anak lebih tenang yang membuatnya semakin percaya diri jika ia sanggup untuk menyelesaikan pekerjaannya dengan baik.

Demikian juga pada peserta didik atau siswa SD untuk kedepannya penelitian ini dapat dimanfaatkan sebagai panduan demi meningkatkan tanggung jawab belajar pada diri siswa. Dan sadar akan betapa pentingnya untuk menanamkan sikap tanggung jawab dalam diri sendiri, akan menjadikan kita sebagai pribadi 
968 Pengaruh Bimbingan Orang Tua Terhadap Tanggung Jawab Belajar Siswa Sekolah Dasar - Niken Ayu Hapsari, Roeth Amarlin Ochrissiati Najoan, Juliana Margareta Sumilat

DOI: https://doi.org/10.31004/edukatif.v4i1.1839

yang luar biasa dimata orang lain. Yang lebih menguntungkan lagi dari sikap tanggung jawab adalah dapat menjadikan kita pribadi yang sukses di masa depan. Perlu di ingat jika sikap tanggung jawab mampu diperoleh jika seorang anak mendengarkan arahan atau bimbingan yang telah diberikan oleh orang tua kepadanya. Dan siswa juga tak harus berfokus pada satu pembelajaran tapi dengan menemukan minat dan bakat akan membuatnya jauh lebih baik menempuh masa depannya.

Penelitian ini mungkin tidak berfokus pada guru-guru namun, di masa depan peneliti berharap jika para guru di sekolah dasar dapat memanfaatkan penelitan milik saya atau peneliti lainnya yang jenis penelitiannya lainnya cukup mirip, sebagai bahan acuan dalam memperhatikan tingkah laku atau sikap siswa saat disekolah apakah terdapat peningkatan ataupun sebaliknya diharapkan guru mampu melakukan konsultasi dengan orang tua siswa agar secepatnya dapat ditindak lanjuti.

\section{KESIMPULAN}

Dari hasil penelitian dan pembahasan di atas maka dapat disimpulkan bahwa terdapat pengaruh signifikan antara bimbingan orang tua terhadap tanggung jawab belajar siswa kelas V SD, hal ini dapat dilihat dari hasil pengujian hipotesis menggunakan uji-t sehingga diperoleh nilai $t_{\text {hitung }} 6,942>t_{\text {tabel }}$ 2,012 dengan koefisien determinasinya 97,03\%. Bimbingan orang tua yang diberikan secara terus menerus dapat membangun sikap tanggung jawab belajar siswa secara permanen jika bimbingan yang diberikan secara berkala atau bertahap yang disesuaikan dengan perkembangan anak.

\section{UCAPAN TERIMA KASIH}

Terima kasih kepada Ibu Dr. Juliana M Sumilat, M.Pd dan Ibu Dr. Roeth A O Najoan, M.Pd selaku dosen pembimbing yang telah mengarahkan peneliti dalam melaksanakan penelitian ini. Terima kasih kepada kepala sekolah V SD Negeri II Tomohon yang telah mengizinkan peneliti untuk melakukan penelitian serta ikut membantu pelaksanaan penelitian ini hingga selesai. Terima kasih kepada guru wali kelas VA dan VB yang telah membantu peneliti menuntun siswa agar lebih tertib. Serta terima kasih kepada seluruh siswa kelas VA dan VB yang telah ikut berpatisipasi dalam penyelesaian penelitian saya.

\section{DAFTAR PUSTAKA}

Aliyah, Amira. 2019. “” Adalah Lebih Besar Daripada “R.” Jurnal Pai Raden Fatah 1(2):128-38.

Ansel, Maria Finsensia, And Natalia Pawe. 2021. "Pengaruh Bimbingan Belajar Orangtua Terhadap Disiplin Belajar Siswa Sekolah Dasar." Prima Magistra: Jurnal Ilmiah Kependidikan 2(2):301-12. Doi: 10.37478/Jpm.V2i2.1209.

Astuti, Sinta Indi, Septo Pawelas Arso, And Putri Asmita Wigati. 2015. "Analisis Standar Pelayanan Minimal P." Analisis Standar Pelayanan Minimal Pada Instalasi Rawat Jalan Di Rsud Kota Semarang 3:103-11.

Basri, Muhammad. 2018. "Pengaruh Bimbingan Orang Tua Terhadap Prestasi Belajar Murid Kelas Iv Sd Inpres Bertingkat Kecamatan Somba Opu Kabupaten Gowa." Jkpd (Jurnal Kajian Pendidikan Dasar) 2(2):300. Doi: 10.26618/Jkpd.V2i2.1087.

Hariandi, Ahmad, Yanda Irawan, Article Information, Desi Dwi Hastuti, Sutama, Djalal Fuadi, Yuliananingsih Yuliananingsih, Teresius Darmo, Nurlita Maulida, Mira Mirawati, Wawan Syahiril Anwar, Ana Mar Atul Hasanah, Suharso, Sinta Saraswato, Layanan Konseling Behavioral, Hubungan Antara, Self Efficacy, Tanggung Jawab, D. A. N. Minat Belajar, Rizka Aprilia Dewi, Isa Ansori, Meita Wida, Ayu Prihastutia, Rini Mulyani, And Tatang Muhajang. 2020. "Analisis Karakter Tanggung Jawab Pada Siswa Kelas Iv.” Jppguseda | Jurnal Pendidikan \& Pengajaran Guru Sekolah Dasar 3(1):64-71. 
Jeklin, Andrew. 2016. "Pengaruh Bimbingan Belajar Oleh Orang Tua Dan Motivasi Belajar Bagi Siswa Terhadap Tanggung Jawab Belajar Siswa Kelas V Sd Negeri Tegalglagah 04 Bulakamba Brebes." 3(July):1-23.

Juniarti, Lisa. 2021. "Pengaruh Bimbingan Orang Tua Dalam Pembelajaran Dari Rumah Terhadap Motivasi Belajar Siswa Mi Plus Nur Rahma Kota Bengkulu."

Lagiana, Tri. 2017. "Pengaruh Bimbingan Orang Tua Dan Pola Asuh Orang Tua Terhadap Perilaku Belajar Siswa Kelas Iv Dan V Di Sd Negeri 2 Grogol Sawoo Ponorogo Tahun Ajaran 2016/2017." Institut Agama Islam Negeri 1(1):1-130.

Melati, Reni Sofia, Sekar Dwi Ardianti, And Much Arsyad Fardani. 2021. "Analisis Karakter Disiplin Dan Tanggung Jawab Siswa Sekolah Dasar Pada Masa Pembelajaran Daring." Edukatif: Jurnal Ilmu Pendidikan 3(5):3062-71.

Monica, Mega Aria, And Ruslan Abdul Gani. 2016. "Efektivitas Layanan Konseling Behavioral Dengan Teknik Self-Management Untuk Mengembangkan Tanggung Jawab Belajar Pada Peserta Didik Kelas Xi Sma Al-Azhar 3 Bandar Lampung Tahun Ajaran 2015/2016." Konseli: Jurnal Bimbingan Dan Konseling (E-Journal) 3(2):113-26.

Najoan, Roeth A. O. 2011. "Performance Assessment Based Learning Problem On Models Team Assisted Individualization (Tai)." Jurnal Evaluasi Pendidikan 2(2):193-205.

Nasehudin, T. S., And N. Gozali. 2012. "Metode Penelitian Kuantitatif". Bandung: Pustaka Setia.

Nugraheni, Dwi. 2015. "Pengaruh Bimbingan Belajar Orang Tua Terhadap Prestasi Belajar Siswa Kelas Tinggi Sd Negeri Jagoan 1 Tahun Ajaran 2014/2015.” 151:10-17. Doi: 10.1145/3132847.3132886.

Pangastuti, Ratna, Fifi Pratiwi, Alma'atus Fahyuni, And Kammariyati Kammariyati. 2020. "Pengaruh Pendampingan Orangtua Terhadap Kemandirian Dan Tanggung Jawab Anak Selama Belajar Dari Rumah." Jeced: Journal Of Early Childhood Education And Development 2(2):132-46. Doi: 10.15642/Jeced.V2i2.727.

Parnata, Wayan, M. .. Rini Kristiantari, And Db. Kt. Ngr. Semara Putra. 2014. "Hubungan Bimbingan Belajar Orang Tua Dan Konsep Diri Dengan Hasil Belajar Matematika Siswa Kelas V Sd Gugus V Tampaksiring." Mimbar Pgsd Undiksha 2(1):1-10.

Pratiwi, Novita, And Aslam. 2021. "Pengaruh Model Pembelajaran Picture And Picture Terhadap Kemampuan Berpikir Kreatif Siswa Di Sekolah Dasar.” Jurnal Ilmu Pendidikan Vol 3(6):3697-3703.

Putra, Bagus Asta Iswara, And A. A. Sagung Kartika Dewi. 2016. "Pengaruh Kepuasan Kerja Dan Komitmen Organisaional Terhadap Organizational Citizenship Behavior Bagus Asta Iswara Putra 1 Fakultas Ekonomi Dan Bisnis Universitas Udayana ( Unud ), Bali , Indonesia Sumber Daya Manusia Masih Menjadi Sorotan Bagi Organisasi." Manajemen Unud 5(8):4892-4920.

Sumilat J M. 2020. Media In Learning During The Pandemic. 1st Ed. Edited By Palilingan R V. Tondano: Unima Press.

Syafitri, Rodhiyah. 2017. "Meningkatkan Tanggung Jawab Belajar Melalui Strategi Giving Questions And Getting Answers Pada Siswa." Jurnal Penelitian Dan Pengembangan Pendidikan 1(2):57-63. Doi: 10.23887/Jppp.V1i2.12623.

Tarbiyah, Jurusan, Program Studi, Pendidikan Agama, Sekolah Tinggi, And Agama Islam. 2010. "Pengaruh Bimbingan Belajar Orang Tua Terhadap Tanggung Jawab Belajar Anak Kelas Iv Pada Sdn Egeriw Onoyoso Pringapus Semarang Tahun 2010.” 